\title{
PENGEMBANGAN KAPAL PERIKANAN TRIMARAN: KAJIAN MENGENAI KEBUTUHAN TENAGA KAPAL, KEAMANAN DAN KENYAMANAN
}

\author{
Richard Benny Luhulima ${ }^{1, *}$ \\ ${ }^{1}$ Jurusan Teknik Perkapalan Fakultas Teknik Universitas Pattimura, Ambon 97233 \\ *Email: richardluhulima26@gmail.com
}

\begin{abstract}
Abstrak. Secara umum armada penangkapan ikan yang beroperasi di perairan Maluku dan dikelola oleh pengusaha lokal terdiri dari kapal penangkap ikan monohull dan trimaran dengan cadik. Kapal penangkap ikan monohull memiliki ruang geladak yang terbatas dan stabilitas melintang yang kurang baik, sedangkan kapal jenis trimaran memiliki ruang geladak yang lebih baik dan stabilitas melintang dibandingkan kapal monohull, namun karena masih dalam bentuk cadik maka ruangnya terbatas. Penelitian ini bertujuan untuk mengkaji perkembangan kapal penangkap ikan trimaran ditinjau dari kebutuhan energi, keselamatan dan kenyamanan awak kapal selama operasi penangkapan. Tahap awal penelitian ini diawali dengan analisis data dan ukuran pokok kapal penangkap ikan monohull yang beroperasi di perairan Maluku, dari data tersebut dirancang bentuk lambung kapal trimaran. Perhitungan hambatan dengan menggunakan CFD, kemudian dianalisis perhitungan hambatan dan stabilitas, keselamatan dan kenyamanan kapal dengan menggunakan Maxsurf. Kapal Trimaran hambatan memiliki 8,86\% lebih kecil dari monohull dan 3,25\% lebih kecil dari katamaran. Pengunaan Energi (EHP) terbukti kapal trimaran lebih dari mode kapal lainya. Periode trimaran rata-rata adalah 10,5 detik yang memenuhi standar IMO dan dinyatakan baik untuk operasional.
\end{abstract}

Kata kunci: Kapal Perikanan Trimaran, Hambatan, Kebutuhan Daya, Kenyamanan

\begin{abstract}
In general, the fishing fleets operating in Maluku waters are consisted of monohull and trimaran vessels with outriggers managed by local entrepreneurs. Monohull fishing vessels have limited deck space and low transverse stability, whereas trimaran fishing vessels have more deck space and greater transverse stability than monohull fishing vessels, but space is still limited due to their outrigger shape. This study aimed to analyze the development of the trimaran fishing vessel in terms of energy requirements, safety and comfort of the crew during fishing operations. At the beginning of this research, data analysis was undertaken and the basic size of monohull fishing vessels operating in Maluku waters, from this data the shape of the trimaran hull was then designed. Resistance was calculated using CFD, and then the resistance, stability, safety, and comfort of the ship were examined using Maxsurf. The trimaran vessel's barrier was $8.86 \%$ smaller than a monohull and $3.25 \%$ smaller than a catamaran. Trimaran vessels consumed more energy than other vessel types. The average trimaran period was 10.5 seconds which met IMO standards and was declared as operationally good.
\end{abstract}

Keywords: Trimaran Fishing Vessel, Barriers, Power Requirements, Comfort

\section{PENDAHULUAN}

Sebagai provinsi yang $92 \%$ wilayahnya merupakan perairan, sektor kelautan dan perikanan di Provinsi Maluku merupakan sumber utama pertumbuhan ekonomi di wilayah tersebut. Potensi perikanan tangkap di Maluku tercatat 1,72 juta per tahun. Hal ini mendorong pemerintah Indonesia menetapkan Maluku sebagai "Lumbung Ikan Nasional". Dalam konteks global, Maluku merupakan bagian penting dari keanekaragaman hayati laut dunia, mengingat provinsi ini memiliki 
$76 \%$ jenis karang dunia dan $37 \%$ jenis ikan karang dunia.

Penangkapan ikan berlebihan merupakan salah satu ancaman utama bagi sektor perikanan Maluku yang meliputi eksploitasi udang dan tuna mata besar, kakap, kerapu, flying fish, dan tuna albakora. Minimnya ketersediaan data, misalnya data terkait ikan pelagis kecil dan ikan pelagis besar serta jenis migrasi serta informasi nilai dan status terumbu karang, padang lamun dan ekosistem muara (muara) di Provinsi Maluku menjadi tantangan lain. dalam upaya pengelolaan perikanan di Provinsi Maluku. Pengelolaan kawasan konservasi laut yang belum optimal menambah daftar panjang ancaman sektor perikanan Maluku. Pengembangan wilayah pesisir yang tidak ramah lingkungan serta pencemaran akibat pengembangan perairan umum perlu dikelola melalui perencanaan zonasi perairan yang baik. Upaya penegakan hukum diperlukan untuk mengatasi maraknya praktik penangkapan ikan ilegal, tidak diatur dan tidak dilaporkan (Illegal, Unregulated, and Unreported/ IUU Fishing), penangkapan ikan hiu, praktik penangkapan ikan yang merusak, kejahatan terhadap satwa liar, dan kurangnya kapasitas pemangku kepentingan terkait.

Nelayan perlu memiliki perahu yang bagus untuk bisa menangkap ikan secara optimal. Kapal nelayan yang beroperasi di perairan Maluku sering mengalami kecelakaan di laut pada saat melakukan operasi penangkapan ikan yang disebabkan oleh faktor cuaca ekstrim, overloading dan human error. Salah satu cara untuk meningkatkan stabilitas kapal nelayan adalah dengan mengubah bentuk lambung monohull menjadi trimaran. Pasalnya, bentuk kapal monohull yang banyak dijumpai di perairan Maluku memiliki beberapa kekurangan terkait stabilitas kapal, serta keterbatasan ruang muat. Keunggulan trimaran adalah memiliki stabilitas yang lebih baik, daya jelajah yang lebih jauh, serta memiliki hambatan dan gesekan kapal yang lebih kecil dibandingkan dengan lambung monohull [1]. Oleh karena itu sebagai upaya meminimalisir kecelakaan kapal dapat dilakukan dengan penerapan penggunaan kapal jenis trimaran sebagai salah satu alternatif dalam pengadaan dan penambahan kapal penangkap ikan di Maluku. Kapal Trimaran merupakan pengembangan dari model kapal dengan sistem multi lambung. Kapal trimaran memiliki beberapa keunggulan dibandingkan kapal monohull [2], misalnya pada ukuran kapal dengan lebar yang sama maka tahanan gesek kapal trimaran lebih kecil, sehingga memiliki daya dorong dengan kecepatan yang sama lebih besar. Area geladak kapal trimaran lebih lebar dari pada kapal dengan tipe lambung kapal monohull. Volume terendam dan area basah yang relatif lebih kecil, stabilitas lebih baik karena memiliki banyak lambung [3].

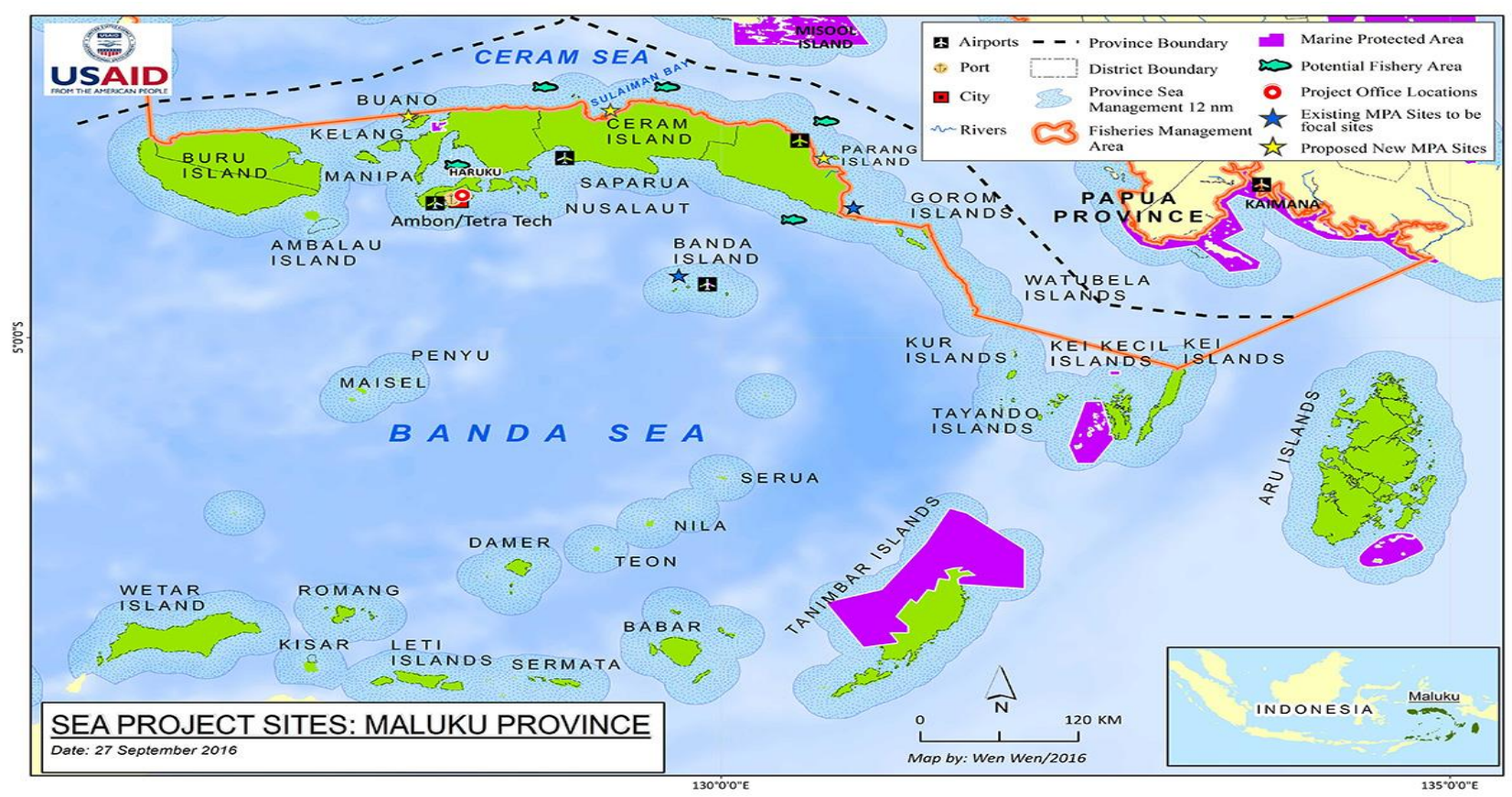

Gambar 1. Provinsi Maluku 
Pengembangan kapal penangkap ikan Trimaran belum pernah dilakukan oleh instansi dalam maupun luar negeri. Pemilihan Hull Trimaran sangat penting karena memiliki permukaan dek yang besar dan juga memiliki stabilitas yang baik. Permukaan geladak yang besar memungkinkan anggota kru bergerak dengan bebas. Kapal Perikanan Trimaran merupakan salah satu bentuk Rencana Strategis Unggulan UNPATTI untuk menjadi pusat rujukan ilmu pengetahuan dan teknologi nasional di bidang Pelayaran dan Perikanan.

Tujuan penelitian ini adalah untuk mendapatkan bentuk lambung kapal nelayan trimaran. Penelitian ini difokuskan pada kajian pengembangan kapal penangkap ikan trimaran ditinjau dari kebutuhan energi, keamanan dan kenyamanan kapal selama operasi penangkapan. Rumusan masalah yang dirumuskan adalah: Analisis perkembangan kapal penangkap ikan trimaran ditinjau dari aspek kebutuhan energi, keselamatan dan kenyamanan nakhoda dan awak kapal. Tujuan umum dari penelitian ini adalah untuk meminimalkan kecelakaan kapal penangkap ikan selama operasi di tempat penangkapan ikan dan mengurangi Power.

Dari penelitian yang dilakukan dapat diperoleh model kapal ikan trimaran yang efektif dan hemat daya. Hasil dari teknologi tersebut diharapkan dapat dimanfaatkan dengan baik untuk meningkatkan hasil tangkapan yang optimal dan memenuhi kriteria keamanan lingkungan serta memperoleh hasil tangkapan yang melimpah.

\section{BAHAN DAN METODE}

\subsection{Prosedur Penelitian dan Persamaan}

Dalam simulasi akan diketahui besarnya komponen tahanan yang bekerja pada lambung trimaran. Simulasi pemodelan permukaan bebas (pada media air dan udara) digunakan untuk menghitung hambatan total pada lambung kapal. Dinding domain fluida dalam kondisi free slip yaitu tegangan geser pada dinding bernilai nol dan kecepatan di dekat dinding tidak mengalami perlambatan akibat pengaruh gesekan dinding. Dalam simulasi ini, model dibuat dalam kondisi tanpa selip (yaitu terjadi gesekan pada permukaan model). Sedangkan untuk menghitung tahanan kental, lambung kapal dibenamkan (dalam media air) sampai penuh dengan air dengan asumsi kondisi batas atas dinding kokoh dan bebas slip. Kemudian hambatan gelombang dapat dihitung dari selisih nilai hambatan total dan hambatan viskos

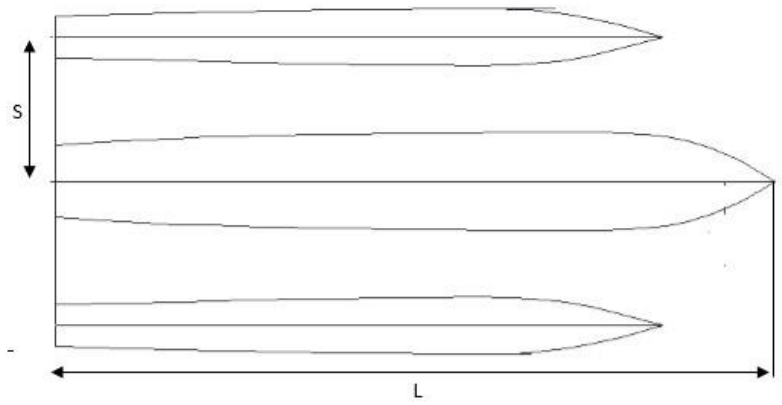

(a) Model Trimaran

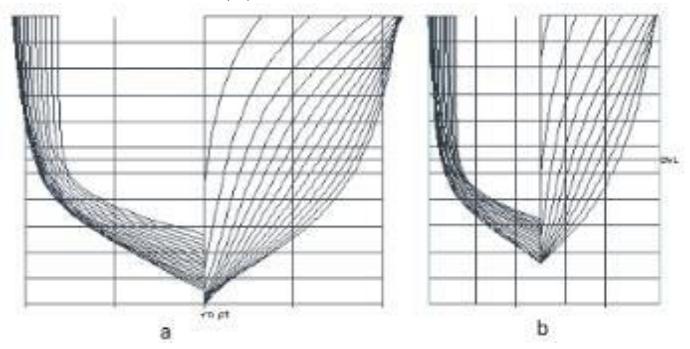

(b) Body Plan

Gambar 2. Trimaran Configuration, $\mathrm{S} / \mathrm{L}=0.2$

\subsection{Metodologi}

\section{Konvergensi}

Pada tahap ini, proses iterasi perhitungan akan selalu dikontrol oleh persamaan pengendali. Jika hasil perhitungan tidak sesuai dengan tingkat kesalahan yang ditentukan, maka perhitungan akan dilanjutkan. Berikut ini adalah beberapa grafik RMS yang menunjukkan konvergensi dari proses iterasi, seperti yang ditunjukkan pada Gambar 3

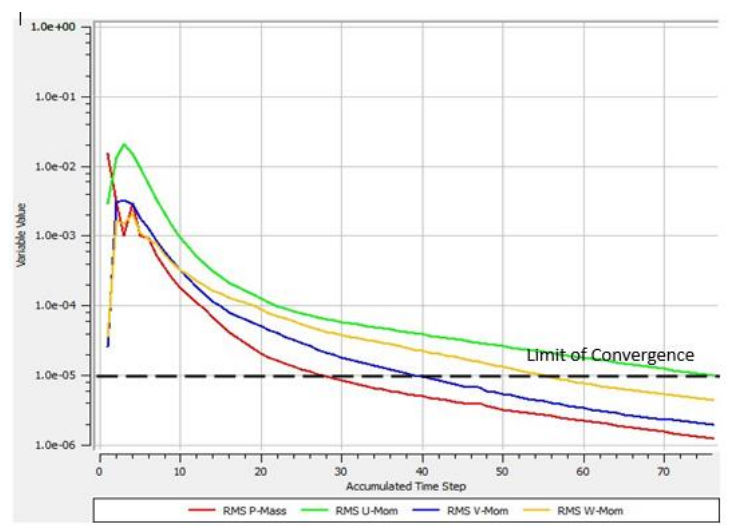

Gambar 3. Konvergensi

Kriteria root-mean square (RMS) yang digunakan untuk memeriksa konvergensi simulasi permukaan bebas adalah nilai target sisa (nilai variabel) yang mencapai $10^{-5}$. Kriteria target (nilai variabel) diterapkan secara luas dalam rekayasa komputasi, seperti yang direkomendasikan dalam manual ANSYS ICEM [5] dan [6]. 


\section{Grid Independence}

Banyaknya sel atau grid yang digunakan dalam perhitungan akan menentukan keakuratan hasil yang diperoleh karena banyaknya sel mempengaruhi perubahan bentuk geometris selama pemrosesan hasil. Gambar 5.2 menunjukkan domain komputasi awal. Batas boudary di depan lambung mencapai 1,5 kali panjang model lambung, di belakang lambung 4 kali panjang lambung. Kemudian panjang model ke samping 1,5 kali, dan jarak di atas 2,5 kali panjang model dan di bawah 2 kali panjang model lambung. Jarak ini cukup untuk menghindari efek penyumbatan [7], [8]. Perhitungan mesh yang digunakan (perhitungan aliran multifase) terdiri dari 1.582.580 elemen grid

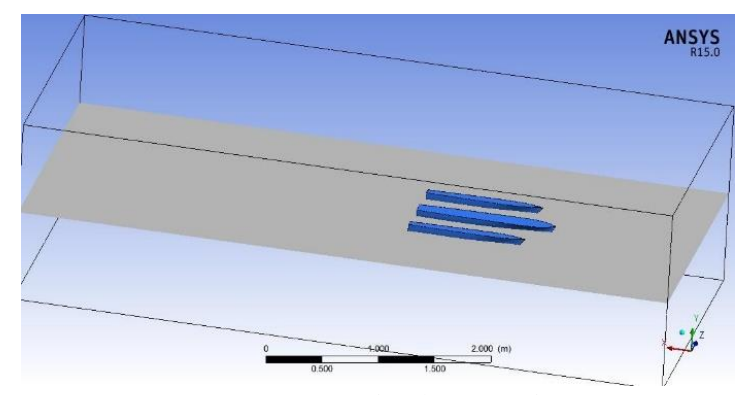

(a) Numerical Domain

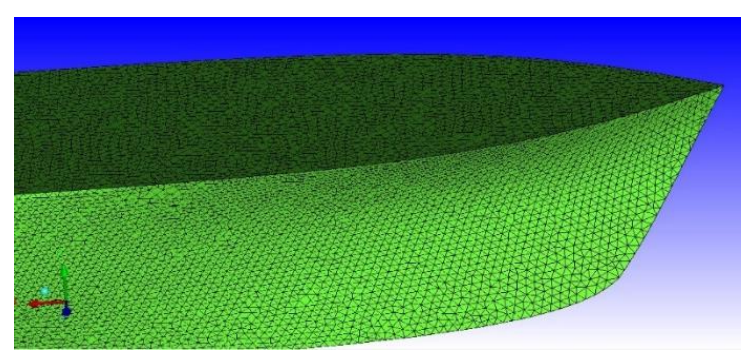

(b) Mesing Model

Gambar 4. Simulai Model Trimaran

Kualitas atau jumlah mesh grid sangat penting untuk konvergensi dan akurasi simulasi / perhitungan CFD. Kualitas dan nilai grid dibahas secara rinci oleh [9] dan [10]. Jumlah elemen jaring, 1582.580 untuk lambung trimaran cukup optimal dan akurat, dimana jumlah elemen yang digunakan dalam perhitungan menunjukkan bahwa grid independent. Nilai resistansi untuk jumlah elemen jaring (grid) 1.582 .580 dan 2.875.830 adalah konstan dan sama. Sehingga dapat dikatakan bahwa 1.582.580 mesh number yang terpilih pada komputasi CFD telah memenuhi tingkat akurasi yang cukup baik

\section{HASIL DAN PEMBAHASAN}

\subsection{Hambatan dan Daya}

Koefisien komponen drag trimaran simetris dalam konfigurasi jarak transversal lambung $(\mathrm{S} / \mathrm{L})$. Untuk konfigurasi lambung kapal trimaran $\mathrm{S} / \mathrm{L}=$ 0,2 , disajikan secara pada Tabel 1 yang menunjukkan bahwa tahanan kental lebih besar (dominan) daripada tahanan gelombang pada $\mathrm{Fr}$ $<0,27$. Hal ini dikarenakan jarak lambung yang cukup dekat sehingga fluida antar lambung yang mengenai lambung kapal akan terpantul ke lambung lain yang berada di aliran dalam.

Koefisien tahanan kental sangat dominan pada Fr $<0,22$ kemudian pada S / L > 0,22 Koefisien tahanan gelombang mulai meningkat, tetapi koefisien tahanan kental lebih dominan pada S / L $<0,27$. Hal ini ditunjukkan pada tabel 1 . Gambar 5 menunjukkan bahwa interferensi viskos lebih dominan daripada interferensi resistansi.

Tabel 1. Koefisien Hambatan Kapal

\begin{tabular}{cccc}
\hline Fr & $\begin{array}{c}\text { Koefisien } \\
\text { Hambatan } \\
\text { Total }\left(\mathrm{C}_{\mathrm{T}}\right)\end{array}$ & $\begin{array}{c}\text { Koefisien } \\
\text { Hambatan } \\
\text { Viskos }\left(\mathrm{C}_{\mathrm{T}}\right)\end{array}$ & $\begin{array}{c}\text { Koefisien } \\
\text { Hambatan } \\
\text { Gelombang } \\
\left(\mathrm{C}_{\mathrm{T}}\right)\end{array}$ \\
\cline { 2 - 4 } & \multicolumn{3}{c}{$\left(10^{-3}\right)$} \\
0,15 & 4,270 & 3,980 & 0,29 \\
0,17 & 4,558 & 3,820 & 0,738 \\
0,19 & 4,623 & 3,372 & 1,251 \\
0,21 & 5,135 & 3,078 & 2,057 \\
0,23 & 5,608 & 3,164 & 2,444 \\
0,25 & 6,001 & 3,364 & 2,637 \\
0,27 & 6,165 & 3,308 & 2,857 \\
\hline
\end{tabular}

Tabel 2. Koefisien Hambatan Total

\begin{tabular}{cccc}
\hline \multirow{2}{*}{ Fr } & \multicolumn{3}{c}{ CFD } \\
\cline { 2 - 4 } & Monohull & Katamaran & Trimaran \\
\hline 0,15 & 4,491 & 4,291 & 4,270 \\
0,17 & 4,848 & 4,648 & 4,558 \\
0,19 & 5,258 & 4,803 & 4,623 \\
0,21 & 5,965 & 5,265 & 5,135 \\
0,23 & 6,295 & 5,947 & 5,608 \\
0,25 & 6,443 & 6,293 & 6,001 \\
0,27 & 6,653 & 6,333 & 6,165 \\
\hline
\end{tabular}

Kapal trimaran memiliki nilai hambatan yang lebih baik jika dibandingkan dengan mode kapal lainya. Hal ini ditunjukkan pada tabel 2, dimana kapal Trimaran memilki hambatan 8,86\% lebih kecil dari pada monohull dan 3,25\% lebih kecil daripada katamaran. Penurunan hambatan pada tipe trimaran maupun katamaran adalah karena efek positif inferensi antar lambung, dimana pertemuan efek gelombang akibat lambung kapal saling menghilangkan. Akibatnya, aliran antara 
lambung kapal menjadi berkurang, sebagaimana ditunjukkan pada Gambar 5.

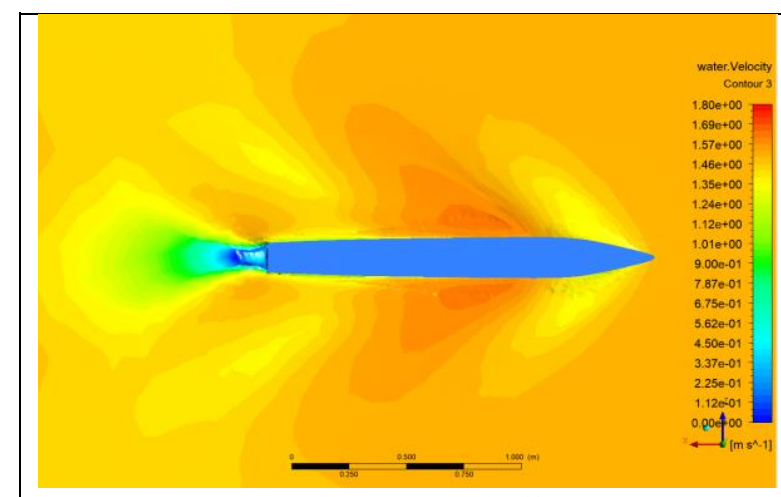

(a) Monohull

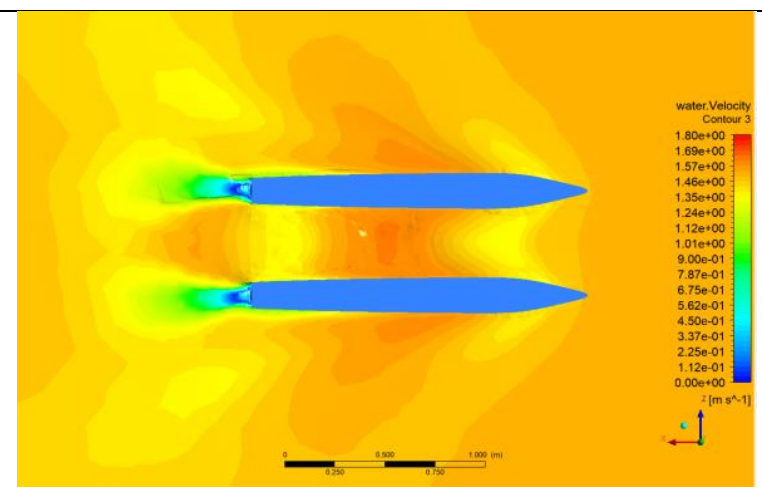

(b)

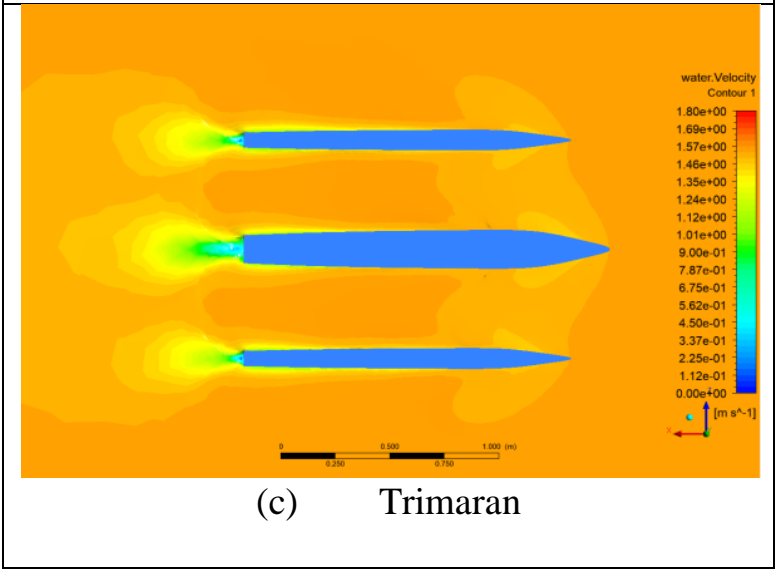

Gambar 5. Distribusi Kecepatan berbagai tipe kapal

Perhitungan Engine Effective Power (EHP) juga menunjukkan kecenderungan yang sama, yaitu kapal trimaran membutuhkan daya paling kecil diantara kapal pembanding lainnya. Hal tersebut ditunjukkan pada Gambar 6. Dimana, kapal Trimaran dengan kecepatan 12 knot membutuhkan tenaga sebesar 608,08 kW, sedangkan untuk katamaran membutuhkan tenaga $629,16 \mathrm{~kW}$ dan kapal monohull membutuhkan tenaga $665,43 \mathrm{~kW}$. Hal ini menunjukkan kapal trimaran memiliki keunggulan dalam menggunakan tenaga mesin yang lebih sedikit.

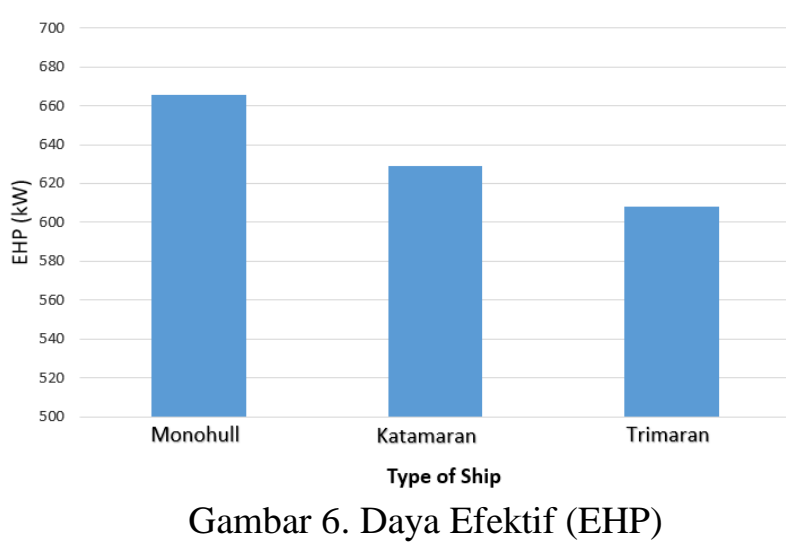

Bentuk flat hull atau thin ship hull (L/B >>), kontribusi hambatan gelombang lebih besar dari pada hambatan gelombang terhadap hambatan total. Resistensi kental (yang didominasi oleh tahanan gesekan) meningkat dengan bertambahnya panjang lambung [11]. Dengan bertambahnya panjang atau luas area basah maka gaya gesek permukaan juga akan meningkat. Sedangkan untuk tahanan gelombang pada umumnya menjadi lebih kecil dengan bertambahnya panjang lambung kapal (untuk displacement tetap).

\section{A. Kenyamanan dan Keselamatan}

Kenyamanan kapal ditunjukkan dengan indikasi pengukuran MSI (Motion Sickness Index) yang ditentukan oleh lokasi jarak jauh di geladak [12]. Sedangkan untuk data gelombang dan arah gelombang yang telah dihitung di atas.

Saat awal beroperasi dengan arah gelombang 1800 (head seas), terjadi MSI maksimal di geladak setelah 2 jam. Dimana, pada saat itu frekuensi encounter sebesar $1.666 \mathrm{~Hz}$ dengan nilai percepatan vertikal sebesar $0.503 \mathrm{~m} / \mathrm{s} 2$. Saat kapal mengikuti ombak (following seas/ 00) maka kapal sangat stabil, dan diprediksi tidak ada awak kapal yang akan mengalami mabuk laut. Pada kondisi kapal melawan gelombang dari arah 1350, di lokasi pengukuran (geladak) maka awak kapal akan mengalami mabuk laut setelah 8 jam pelayaran. Dan kasus tertinggi ditemui pada frekuensi $0,35 \mathrm{~Hz}$ dan percepatan vertikal $0,250 \mathrm{~m} / \mathrm{s} 2$ 


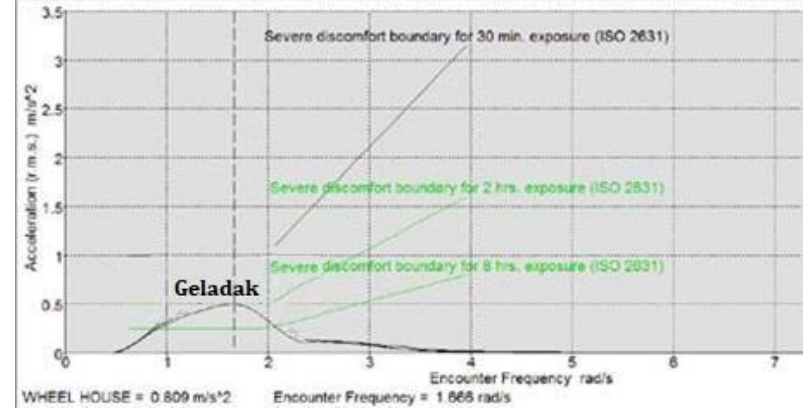

(a)

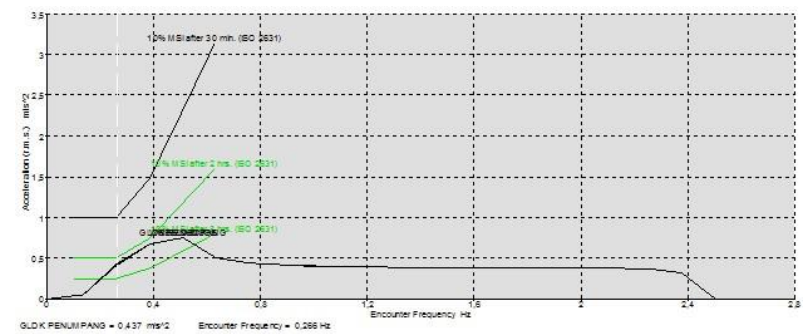

(b)

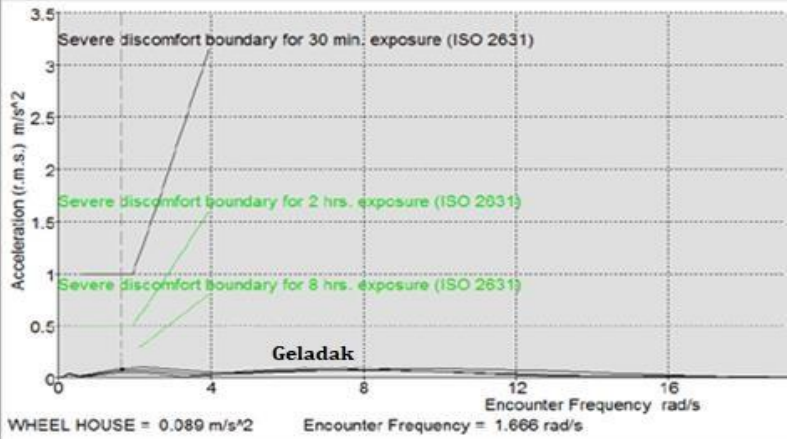

(c)

Gambar 7. MSI KapalTrimaran S/L = 0.2, (a) Heading Seas $\left(180^{\circ}\right)$, (b) Quartering Seas $\left(45^{\circ}\right)$, (c) Following Seas $\left(0^{\circ}\right)$

Menurut [13], periode gelombang dapat dihitung dengan rumus:

$$
T=\frac{2 \pi C B}{\sqrt{g G M}}
$$

Dimana :

$$
\begin{aligned}
\mathrm{T} & =\text { Periode } \\
\mathrm{C} & =0.373+0.023(\mathrm{~B} / \mathrm{D})-0.043(\mathrm{LPP} / 100) \\
& =0.373+0.023(10.4 / 2.85)-0.043(46 / 100) \\
& =0.437 \\
\mathrm{~B} & =\text { Lebar } \\
\mathrm{GM} & =\text { Titik Metacenter }
\end{aligned}
$$

Rumus periode momen:

$$
\begin{aligned}
\text { Periode Momen } & =\text { Displasemen x GM } \\
& =10.5 \mathrm{~s}
\end{aligned}
$$

Waktu guncangan kapal trimaran menurut peraturan International Maritime Organization (IMO) sekitar 10 - 14,5 detik, dan Kapal Trimaran ikan memiliki masa guncangan sekitar 10,5 detik sehingga masih memenuhi persyaratan IMO.

\section{KESIMPULAN}

Dari hasil simulasi perhitungan kapal Trimaran, dapat disimpulkan beberapa hasil sebagai berikut.

1. Kapal trimaran memiliki nilai hambatan yang lebih baik jika dibandingkan dengan mode kapal lainya, Kapal Trimaran memilki hambatan 8,86\% lebih kecil dari pada monohull dan 3,25\% lebih kecil daripada katamaran.

2. Perhitungan EHP pada kecepatan 12 knot menunjukkan Trimaran membutuhkan tenaga sebesar 608,08 kW, sedangkan untuk katamaran membutuhkan tenaga $629,16 \mathrm{~kW}$ dan kapal monohull membutuhkan tenaga $665,43 \mathrm{~kW}$.

3. Kapal Trimaran memiliki respon percepatan vertikal tertinggi saat kapal bergerak melawan arah ombak (heading sea), dimana pada kecepatan kapal 15 knot, tinggi gelombang 2,5 meter dan periode gelombang rata-rata 7,2 detik menyebabkan percepatan vertikal masing-masing $0,806 \mathrm{~m} / \mathrm{s}^{2}$ dan $0,503 \mathrm{~m} / \mathrm{s}^{2} \mathrm{di}$ geladak.

4. Periode guncangan trimaran rata-rata 10,5 detik, sahingga pada trimaran memenuhi standar IMO (10-14,5 detik) dan dinyatakan baik (nyaman).

\section{UCAPAN TERIMA KASIH}

Penulis mengucapkan terima kasih kepada Universitas Pattimura yang telah mendanai penelitian ini.

\section{DAFTAR PUSTAKA}

[1] R. B. Luhulima, I. K. A. P. Utama, and J. H. Chen, "Preliminary study into the selection of passenger and cargo vessels for Eastern Indonesia," in RINA, Royal Institution of Naval Architects International Conference on Ship and Offshore Technology, ICSOT Indonesia 2012: Developments in Ship Design ad Construction, 2012.

[2] R. B. Luhulima and I. K. A. P. Utama, "Selecting Mono- And Multi-Hull Passenger Vessels For Moluccas Waters: Resistance/Powering And Seakeeping Evaluation," in The 13th International Conference on QiR, 25-28 June 2013. Jogjakarta. Indonesia, 2013.

[3] R. B. Luhulima, I. K. A. P. Utama, Sutiyo, and B. Suwasono, "CFD Analysis into the Correlation between Resistance and 
Seakeeping of Trimaran Configuration," in Proceeding of Marine Safety and Maritime Installation (MSMI 2018), 2018, pp. 9-11, doi: $10.23977 / \mathrm{msmi} .2018 .82637$.

[4] ITTC, "ITTC-Recommended Procedures and Guidelines: Practical Guidelines for Ship CFD Applications," 2011.

[5] ANSYS, ANSYS CFX-Solver Theory Guide. Canonsburg, PA, USA: Ansys Inc, 2020.

[6] T. Dinham-Peren, C. Craddock, A. Lebas, and A. Ganguly, "Use Of CFD For Hull Form And Appendage Design Assessment On An Offshore Patrol Vessel And The Identification Of A Wake Focussing Effect," RINAMarine CFD 2008, 2008.

[7] I. K. A. P. Utama, "Investigation of the viscous resistance components of catamaran forms (Ph.D Dissertation)," University of Southampton,UK., 1999.

[8] Y. Ahmed and C. Guedes Soares, "Simulation of free surface flow around a VLCC hull using viscous and potential flow methods," Ocean Eng., 2009, doi: 10.1016/j.oceaneng.2009.03.010.

[9] J. D. Anderson, Computational Fluid Dynamics: The Basics with Applications. New York, USA. pp. 526-532: McGrawHill, 1995.

[10] R. Deng, D. B. Huang, L. Yu, X. K. Cheng, and H. G. Liang, "Research on Factors of a Flow Field Affecting Catamaran Resistance Ralculation," Harbin Gongcheng Daxue Xuebao/Journal Harbin Eng. Univ., 2011, doi: $\quad 10.3969 /$ j.issn.10067043.2011.02.002.

[11] E. O. Tuck, D. C. Scullen, and L. Lazauskas, "Wave Patterns and Minimum Wave Resistance for High-Speed Vessels," 24th Symp. Nav. Hydrodyn., 2002.

[12] IMO, "IMO Train the Trainer (TTT) Course on Energy Efficient Ship Operation," Int. Marit. Organ., no. January, pp. 1-59, 2016.

[13] F. Zouridakis, "A Preliminary Design Tool for Resistance and Powering Prediction of Catamaran Vessels," Massachusetts Institute of Technology, 2005. 